\title{
Unifying the Armed Forces of Bosnia and Herzegovina - mission completed?
}

\section{Unifikace Ozbrojených sil Bosny a Hercegoviny - proces sjednocování}

\section{Věra Stojarová}

Abstract: $\quad$ The Armed Forces of $\mathrm{BiH}$ were officially unified in 2005 and are composed of two founding armies: the Bosniak-Croat Army of the Federation of Bosnia and Herzegovina and the Bosnian Serb Army of Republika Srpska. Even though the unified armed forces celebrated their $13^{\text {th }}$ anniversary in December 2018 and are presented as a success story, the political environment in Bosnia and Herzegovina, particularly in Republika Srpska, does not foster a sense of unity in the armed forces. The paper explores the vulnerabilities that the unified armed forces face, particularly in relation to the process of state building in Bosnia and Herzegovina. The text concludes, that the main concerns for the $\mathrm{BiH}$ armed forces include the old equipment, the economic problems of the country and budget constraints, politicisation and ethnicisation - while ongoing nationalism and the unsure future of $\mathrm{BiH}$ remain the greatest external challenges.

Abstrakt: $\quad$ Ozbrojené síly Bosny a Hercegoviny byly oficiálně sjednoceny v roce 2005 a byly složeny ze dvou zakládajících složek: Armády FBiH a Armády RS. I když sjednocené ozbrojené síly oslavily v prosinci 2018 své třinácté výročí a jsou prezentovány velice pochvalně, politické prostředí v Bosně a Hercegovině, zejména v Republice srbské, nepřispívá k pocitu jednoty ozbrojených sil. Článek se bude zabývat výzvami sjednocených ozbrojených sil ve vztahu k procesu state-buildingu v postkonfliktní Bosně a Hercegovině. K hlavním obavám ozbrojených sil Bosny a Hercegoviny patří staré vybavení, ekonomické problémy země a rozpočtová omezení, politizace a etnicizace; přetrvávající nacionalismus a nejistá budoucnost Bosny a Hercegoviny zůstávají největšími vnějšími problémy.

Keywords: Armed Forces of Bosnia and Herzegovina; Bosnia and Hercegovina; Dayton Peace Agreement.

Klíčová slova: Ozbrojené síly Bosny a Hercegoviny; Bosna a Hercegovina; Daytonská mírová smlouva. 


\section{INTRODUCTION}

The outcome of the war in Bosnia and Herzegovina $(\mathrm{BiH})$ was de facto a divided country and a divided military, and the prospect of unifying the three ethnically-based armies into a single command and control structure seemed utopian. However, the existence of three separate armies was not only a heavy burden for the country's budget, but meant that the units which had fought against each other during the conflict remained separate and would never be able to fight under a unified command. The continuous violence towards returnees, ongoing weapons smuggling and the protests of civilians unhappy with the economic and political transition, helped to strengthen the efforts for demobilisation, cutting the army budgets and final unification. International actors (OHR, OSCE and Nato in particular) helped $\mathrm{BiH}$ to establish the Ministry of Defence in 2004 and the unified Armed Forces of Bosnia and Herzegovina (AFBiH) in 2006. This was probably the greatest achievement in post-Dayton Bosnia and Herzegovina. BiH determined to reduce its military personnel drastically; to unify the armed forces; and to join the Partnership for Peace programme with the final goal of Nato accession. The process of unifying the armed forces was concluded 13 years ago. The question remains of whether the process was successful and whether it is possible to speak of unified armed forces under a unified command; and exclude armed conflict in future.

Existing scholarly accounts of security reform in Bosnia and Herzegovina suggest that a unified military in the country is still an oxymoron. The paper looks closely at the phenomenon of the Armed Forces of Bosnia and Herzegovina and tries to assess the challenges they face. The text also looks at the nexus between the AFBiH and the security of Bosnia and Herzegovina itself and of the region at large. The primary legislation dealing with the defence sector was used as a primary source; several country analyses by different authors were used as secondary sources. Multiple semi-structured interviews with security experts from the Balkan region were undertaken and several surveys undertaken to obtain a better understanding of the issue. My argument is that the Armed Forces of $\mathrm{BiH}$ are far from unified and, unless the country unites, the military cannot be expected to do so. The paper is structured as follows: in the first part the process of unifying the Armed Forces of $\mathrm{BiH}$ is outlined; the second section is devoted to $\mathrm{BiH}^{\prime} \mathrm{s}$ Nato membership aspirations and AFBiH's engagement in the country and abroad; while the third section is devoted to the political, social, economic and other challenges faced by the BiH military.

\section{PROCESS OF UNIFICATION OF THE ARMED FORCES OF BIH}

The Dayton Peace Agreement did not only bring an end to the armed conflict but also resulted in spontaneous demobilisation. Some 370,000 troops under arms (out of an estimated 430,000) left the armed forces in the subsequent five years. The planned demobilisation started three years later. In 1999, the budget for military expenditure was drastically cut by $39 \%$ over the years $1999 / 2000$ and both entities - the Federation of 
$\mathrm{BiH}$ and Republika Srpska (RS) - agreed to reduce military personnel by 15\% in 1999 and by another $15 \%$ the year after. By 2004 , both armies had cut their forces to a combined total of approximately 24,000 active-duty soldiers, supported by some 15,000 reservists and as shown in the graph, in 2016 , the army was down to the current 10,5000 soldiers.

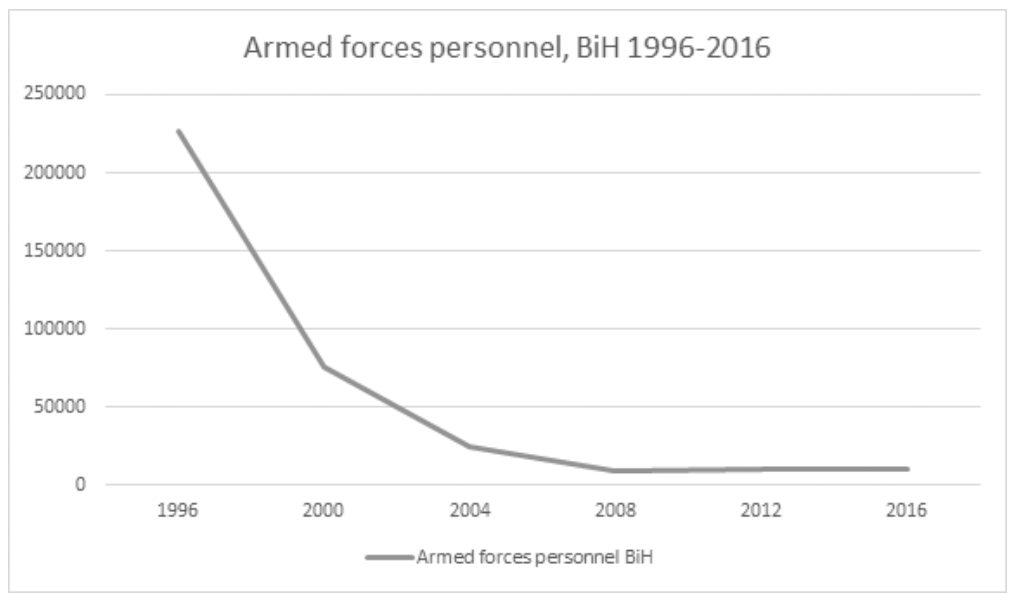

Figure 1: Armed forces personnel, BiH 1996-2016

The Dayton Peace Agreement left the country more divided than it was before the war. It was not just the country that was divided; there were de facto three separate armies in Bosnia and Herzegovina - Bosnian Croat, Muslim (Bosniak) and Bosnian Serb - which were integrated neither structurally nor operationally, with no cooperation between them whatsoever. The international community strove for unification at the level of the single state, but the memories of war were still fresh and the judicial proceedings related to war crimes perpetrated by one of the armies were still ongoing. It was as late as 2004 when the International Court for the former Yugoslavia ruled that the massacre of the male inhabitants of the Srebrenica enclave by the Army of Republika Srpska (Vojska Republike Srpske, VRS) constituted a crime of genocide under international law; the ruling was then upheld by the International Court of Justice in 2007. In spring 2019, Bosnian Serb general Ratko Mladić was sentenced to life in prison for crimes against humanity committed during the Bosnian conflict, inter alia in Srebrenica. Milorad Dodik, Serbian member of the tripartite $\mathrm{BiH}$ presidency and prominent long-term politician in RS, has repeatedly downplayed the Srebrenica massacre, most recently in spring 2019 calling it a "fabricated myth"; other Bosnian Serb politicians also denied the genocide, including Mladen Grujičić, the current mayor of Srebrenica. Republika Srpska set up a commission to establish the "truth" of what occurred; the memories of war were still fresh and present. RS politicians repeatedly claimed there was no will to have joint or unified armed forces and the effort of the international community to establish a single military body in Bosnia and Herzegovina seemed utopian. Some even claimed that the time had come to recognise the reality of a divided country and a divided military. 

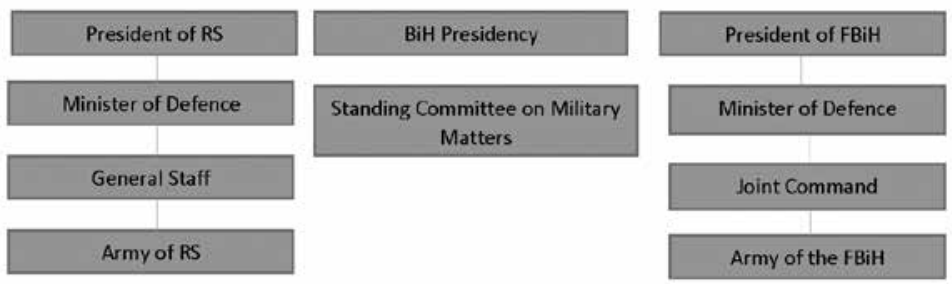

Figure 2: The post-Dayton Command Structure in $\mathrm{BiH}$

International pressure helped the process of unification. In 2003, a Commission for Defence Reform was established, and the first law necessary for a single ministry of defence for $\mathrm{BiH}$ was adopted. State-level parliamentary oversight was created through the establishment of a Defence and Security Committee in the BiH Parliamentary Assembly; on the basis of the Commission's work, ${ }^{1}$ the White Paper on BiH Defence was released in 2005, and further defence legislation was adopted. ${ }^{2}$ In 2004, the first-ever joint collective exercise was conducted between the Army of RS and the Army of FBiH and the whole process of unification was completed around 2006. Thus, the three armies that had fought each other were turned into a single multi-ethnic military force, serving the state of $\mathrm{BiH}$ rather than any particular entity or any of BiH's three constituent peoples. $\mathrm{BiH}$ abolished conscription in 2006 and, in the same year, the presidency defined the size, structure and locations of the newly created $\mathrm{AFBiH} .^{3}$

\begin{tabular}{|l|l|l|l|l|l|}
\hline & Bosnian Serb & Muslim & Bosnian Croat & Other & Total \\
\hline $\mathbf{1 9 9 2 / 9 3}$ & 67,000 & 50,000 & 50,000 & & 167,000 \\
\hline $\mathbf{1 9 9 5 / 9 6}$ & 75,000 & 92,000 & 50,000 & & 217,000 \\
\hline $\mathbf{2 0 0 0 / 0 1}$ & 30,000 & 30,000 & 10,000 & & 70,000 \\
\hline $\mathbf{2 0 1 3}$ & $3,533(33.6 \%)$ & $4,826(45.9 \%)$ & $2,084(19.8 \%)$ & $74(0.7 \%)$ & 10,450 \\
\hline $\mathbf{2 0 1 6}$ & $3,528(33.6 \%)$ & $4,820(45.9 \%)$ & $2,079(19.8 \%)$ & $73(0.7 \%)$ & 10,500 \\
\hline
\end{tabular}

Figure 3: Military Forces in Bosnia and Hercegovina 1992-2013

1 KOMISIJA ZA REFORMU ODBRANE. OSBiH: Jedna vojna sila za 21. vijek. Izvještaj 2005. Sarajevo. http:// www.mod.gov.ba/files/file/dokumenti/Izvjestaj-2005-bs.pdf.

2 MINISTARSTVO ODBRANE. Bijela knjiga odbrane Bosne i Hercegovine. Sarajevo, Juni 2005, http://www. mod.gov.ba/files/file/dokumenti/Bijela-knjiga-bs.pdf; MINISTARSTVO ODBRANE. Vojna doktrina. Sarajevo undated http://www.mod.gov.ba/files/file/dokumenti/vojnadoktrina/vojnadoktrina. pdf. All documents related to defence in $\mathrm{BiH}$ are available at http://www.mod.gov.ba/dokumenti/ odbrambeni_dokumenti/?id=21743.

3 MAXWELL, R., OLSEN, J.A. Destination NATO. Defence Reform in Bosnia and Herzegovina 2003-13. Royal United Service Institute for Defence and Security Studies 2013. https://jfcnaples.nato.int/hqsarajevo/ page14313506/destination-nato-english. 
The AFBiH is not a large military force and according to the latest figures (2018), it has just over 10,000 active-duty soldiers, 1,000 civilians and 5,000 reservists. The composition of the armed forces is based on quotas which are linked to the 1991 census. The current military body consists of more than 3,000 Serbs, almost 5,000 Muslims and over 2,000 Croats. The statistics from 2014 show that women make up $6.6 \%$ of the AFBiH personnel. Women serving in the ranks of the AFBiH are mostly graduates of civilian schools, and obtained further military education through various individual and institutional education programmes.

The armed forces consist of army, air force and air defence units. The branches of the AFBiH are: Infantry, Artillery, Air Defence, Armoured Mechanised Units, Aviation, Engineering, Communications, NBC protection, Electronic Surveillance and Defence, Air Surveillance and Rapid Response and Military Intelligence. Compared with other armed forces in the region, the AFBiH is small, and similar in size to the armed forces of Slovenia (approx. 7,300 personnel).

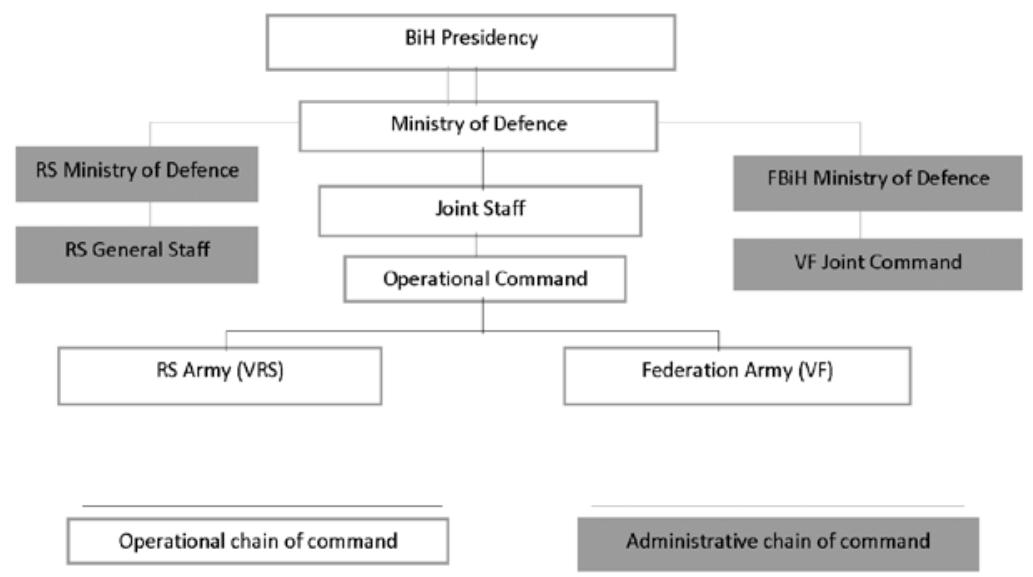

Figure 4: Command and Control of the Armed Forces of $\mathrm{BiH}^{4}$

The military structure is divided into operational and administrative commands, while all of the command structures are multi-ethnic. The mono-ethnic infantry battalions are incorporated into brigades that include battalions from all three constituent nations with the requirement that each ethnicity makes up at least $10 \%$ of the units. ${ }^{5}$ The mission of $\mathrm{AFBiH}$ is defined as: ensuring the sovereignty, territorial integrity, political independence and international legal status of $\mathrm{BiH}$, promoting the $\mathrm{BiH}$ foreign policy goals, meeting the international commitments of $\mathrm{BiH}$, and protecting $\mathrm{BiH}$ nationals. The tasks of the AF$\mathrm{BiH}$ are listed as: participating in collective security operations, peace and self-defence

4 MINISTARSTVO ODBRANE BIH. Bjela knjigao dbrane Bosne i Hercegovine. Sarajevo 2005. http://www.mod.gov.ba/files/file/dokumenti/Bijela-knjiga-bs.pdf.

5 BASSUENER, K. The Armed Forces of Bosnia and Herzegovina: Unfulfilled promise. Berlin /Sarajevo 2015. 
support operations, including the fight against terrorism, providing military defence to $\mathrm{BiH}$ and its citizens in case of attack, assisting the civilian authorities in response to natural and other disasters and catastrophes, clearing landmines in $\mathrm{BiH}$, and meeting $\mathrm{Bi}$ $\mathrm{H}^{\prime}$ s international commitments ${ }^{6}$

\section{NATO MEMBERSHIP ASPIRATIONS AND AFBIH ENGAGEMENT IN BIH AND ABROAD}

Nato played a key role in stabilising Bosnia and Herzegovina in the post-conflict era, through the deployment of peace-keeping forces over a nine-year period from 19952004 until primary responsibility was handed over to the European Union (EU). In 2003, the Presidency of $\mathrm{BiH}$ expressed readiness to engage in the process of Euro-Atlantic integration and actively contribute to collective security. The message consisted of a commitment to include $\mathrm{BiH}$ in European and Euro-Atlantic integration and in the Partnership for Peace programme, and to implement the required defence system reforms and reorganisation of the armed forces. ${ }^{7}$ Nato membership was identified as one of the priorities of foreign policy, as indicated in the Bosnia and Herzegovina Defence White Paper.

In 2006, BiH joined the Partnership for Peace (PfP) programme. An Individual Partnership Action Plan (IPAP) was agreed with Nato in 2008; its goal was to bring together all the cooperation mechanisms through which the country interacts with the Alliance, sharpening the focus of activities to better support domestic reform efforts. Two years later, $\mathrm{BiH}$ was invited to join the Membership Action Plan; in 2018, Alliance foreign ministers decided that Nato was ready to accept the submission of the country's first Annual National Programme. ${ }^{8}$ Nato keeps a military headquarters in Sarajevo to assist the Bosnian authorities with reforms related to the PfP and Nato integration; its secondary goal is to provide logistics and other support to the $\mathrm{EU}$. $\mathrm{BiH}$ has also established a diplomatic mission at Nato Headquarters as well as a liaison office at the Supreme Headquarters Allied Powers Europe (Shape).

From a historical perspective, the relationship between $\mathrm{BiH}$ and Nato is unique. Integration with Nato and membership of PfP was not viewed positively by all three ethnic groups, particularly the Serbs, and certainly not as a historical milestone, which is how it has been presented. Nevertheless, without the prospect of Nato membership or international pressure behind the effort, the country would by no means be willing and able to unify its armed forces and to create an integrated defence system for the whole of Bosnia and Herzegovina.

6 MINISTARSTVO ODBRANE I ORUŽANE SNAGE BOSNE I HERCEGOVINE. Brošura. Sarajevo 2015, http:// www.mod.gov.ba/foto2015/1809-Bosanski\%20jezik-.pdf.

7 DEFENCE REFORM COMISSION. Put u partnerství za mir: Izveštaj komisije za reformu u oblasti odbrane. Sarajevo 2003. http://www.mod.gov.ba/files/file/dokumenti/Partnerstvo-za-mir-bs.pdf.

8 NATO. Relations with Bosnia and Herzegovina. 2008. https://www.nato.int/cps/en/natohq/ topics_49127.htm. 
Despite all of these impediments, the AFBiH has performed admirably both at home and abroad in peace-keeping operations. Even prior to unification, the AFBiH was deployed in Iraq as an all-volunteer force in early 2006. Since $2009, \mathrm{BiH}$ has contributed to the Nato-led International Security Assistance Force (ISAF) in Afghanistan as part of the German and Danish contingents and, following the disbanding of ISAF at the end of 2014, its military has been part of Nato's Resolute Support Mission (RSM) to provide further training, advice and assistance for the Afghan security forces (63 troops out of a total of 17,034 provided by 39 contributing nations). ${ }^{9}$ The AFBiH also performed well during the 2014 flood emergency, saving the lives and property of BiH citizens. Their effort was praised and their reputation enhanced after the floods. The AFBiH worked closely with EUFOR which provided them with helicopters to evacuate people, was involved in delivering humanitarian aid and in clean-up activities. However, the natural disaster also showed the military's deficiencies in equipment, training and preparation for situations of this kind. ${ }^{10}$ Another challenge that AFBiH has been facing is demining, since landmines are still killing people in $\mathrm{BiH}$.

\section{Challenges fOR the AFBiH}

\subsection{Internal challenges}

One of the first issues the armed forces had to face was property and equipment. The only defe3nce premises controlled directly by the state of $\mathrm{BiH}$ were the offices occupied by the MoD, Joint Staff and Operational Command, and the only equipment consisted of the weapons, ammunition and vehicles deployed in Iraq. Everything else was controlled by the entities (Federation of $\mathrm{BiH}$ and Republika Srpska) and was of a scale suitable for much larger forces than AFBiH. Finally it was agreed that the real estate (required for defence purposes) would be transferred from the entities to the state. The arms, weapons and equipment (AWE) became the subject of heated discussions, as the international community did not want them to fall into the wrong hands.

In 2008, it was finally agreed that $\mathrm{BiH}$ should comply with its obligations under international law to minimise the proliferation of $A W E$, and that weapons and equipment would become state property, pending disposal of surplus items. Further discussion focused on the disposal of surplus AWE (an estimated 18,000 tons) - Bosnian policy-makers wanted

9 NATO. RSM. Key facts and figures. 2019. https://www.nato.int/nato_static_fl2014/assets/pdf/ pdf_2019_03/20190305_2019-03-RSM-Placemat.pdf.

10 EUROPEAN COMMISION. Floods in Bosnia and Herzegovina. 2014. http://ec.europa.eu/echo/files/ news/bosnia herzegovina_floods_joint_report_en.pdf; HUSEINBASIC, S. Floods in Bosnia and Herzegovina. Lessons to learn. 2014. https://www.coe.int/t/dg4/majorhazards/activites/2014/ SamirHuseinbqsic_BiH_Floods.pdf. 
this disposal to occur through sales, while the international community pressed consistently for the dismantling or destruction of surplus items. The final agreement was that the state should retain $20 \%$ of any profits from sale while the remaining $80 \%$ would go to the entity originally owning the AWE. This of course proved to be controversial and hard to implement given the mutual suspicions of both entities regarding the transparency of the disposal process and associated profits. Moreover, another problem, which will only emerge in time, is the age of the AWE which raises safety and security concerns, including the risk of leakage from storage sites due to the poor storage conditions. ${ }^{11}$ The registration of immovable defence property was also a reason why Nato held up the accession process until 2018. Even though Nato decided to move forward, deciding not to allow Republika Srpska to block the whole process, the property must still be registered at the federal level for the Membership Action Plan to conclude.

Experts have emphasised that budget constraints have had an effect on the quality of equipment and training: „Only one-third of the engineering equipment is operational by peacetime standards, in a war situation it's a lot more. "12 Azra Mulahasanović, the OSCE senior public information officer, stated that "more than $90 \%$ of the allocated budget is spent on personnel costs (i.e., salaries), only a relatively small portion on maintenance, and almost nothing on procurement." ${ }^{13}$ Selmo Cikotić, former minister of defence, also highlighted the lack of money: ' $\mathrm{BiH}$ 's defence budget, which is around $1 \%$ of GDP, is not enough - it would have to be doubled to reach Nato standards in this regard."14

Some challenges for AFBiH also lie in the system as such and in structural changes. Marina Pendeš, who was appointed minister of defence in 2015, was charged with negligent performance of official duties and with forging documents in 2016. A year later, she was acquitted by the court of all charges and remained in post. Many experts agree that the continuing politicisation of the army is related not only to the positions in the MoD but also to key positions in the structure. Another problem is the constitutional setting, as the important posts are all appointed on an ethnic, rather than professional, basis and according to links to political parties. The practice of sending Serbs for supplementary training in Serbia, Croats to Croatia and Bosniaks to Turkey also reveals the persistent polarisation in the army ranks. Some of the experts also described ostentatious displays of religiosity for personal advancement. The evidence of religious/party patronage in the army emerged when it was leaked that the MoD was funding Hajj pilgrimages to Mecca and Orthodox devotional trips to Greece for some AFBiH members. ${ }^{15}$ All of my interviewees stated that ethnic polarisation prevails and that "according to the information available to the general public, the army uses nationalistic flags, symbols, heraldic signs and also

11 MAXWELL, R., OLSEN, J.A. Destination NATO. Defence Reform in Bosnia and Herzegovina 2003-13. Royal United Service Institute for Defence and Security Studies 2013. https://jfcnaples.nato.int/hqsarajevo/ page14313506/destination-nato-english.

12 BASSUENER, K. The Armed Forces of Bosnia and Herzegovina: Unfulfilled promise. Berlin /Sarajevo 2015.

13 MULAHASANOVIĆ, Azra. Senior Public Officer at OSCE. Questionnaire via email, 26 March 2019, Sarajevo.

14 CIKOTIĆ, Selmo. Former Minister of Defence. Questionnaire via email, 18 April 2019, Sarajevo.

15 BASSUENER, K. The Armed Forces of Bosnia and Herzegovina: Unfulfilled promise. Berlin /Sarajevo 2015. 
the anthems of other states. "16 Most of the interviewees agreed that they could not imagine the $\mathrm{AFBiH}$ instigating destabilisation in $\mathrm{BiH}$, though there was unanimous agreement that - should something trigger an armed conflict in $\mathrm{BiH}$ - „,in this situation three national armies would again emerge as $\mathrm{BiH}$ is a much more divided society than in $1992 " .{ }^{17}$

\subsection{External drivers - economy, politics and society}

Even though the representatives of $\mathrm{BiH}$ stress the progress made and the will for a peaceful future, ${ }^{18} 24$ years after signing the Dayton Peace Agreement, the country has not recovered from the impact of the war and is still facing the challenges of economic transition from a state economy to a free-market one. The budget constraints and the demobilisation of the army coincided with high unemployment and difficult re-integration of ex-combatants into civilian life. Their military background proved to be a disadvantage when seeking civilian jobs. The high unemployment rate has also been fed by the return of refugees and the minimal opportunities for returnees in the labour market. The grey market, unofficial economy and organised crime flourished while pension payments were delayed - this was made worse by the poor state of the economy overall. Last but not least, the country contributed to the export of mercenaries to other parts of the world (Bosniaks joined Chechen fighters in 2000 and assisted the Kosovo Liberation Army in 1999; Bosnian Serbs assisted Yugoslav security forces in Kosovo in 1998 and were also part of the White Legion in Zaire fighting on the side of President Mobutu Sésé Seko during the First Congo War in 1996). ${ }^{19}$

The political climate in Bosnia and Herzegovina has worsened since the Dayton Peace Agreement. The Peace Accords stopped the war which caused a great many casualties, but they also created a dysfunctional state, in which part of the population does not want to live and where mutual trust has not been established. The government of Republika Srpska has for years ruled out joining Nato and emphasised the 2017 Resolution on its military neutrality, pointing to the Nato air campaigns against RS and Serbia respectively during the 1990s. Dodik has been calling for the demilitarisation and neutrality of the country while misusing the AFBiH for political purposes. In early 2017, the US Department of the Treasury's Office of Foreign Assets Control introduced sanctions against Dodik, saying he posed a "significant threat to the sovereignty and territorial integrity of Bosnia and Herzegovina." ${ }^{20}$ The sanctions block Dodik's access to assets and

16 JOVICIĆ, Dragomir. Interview, October 2018, Sarajevo.

17 JOVICIĆ, Dragomir. Questionnaire via email. 20 March 2019.

18 Interview with Selmo Cikotić, former defence minister of $\mathrm{BiH}, 2013$. Available at https://www.youtube. com/watch?v=akmi6KDqpVs.

19 KING, J., DORN, W., HODES, M. An unprecedented experiment: Security sector reform in Bosnia and Herzegovina, Bonn 2002.

20 US EMBASSY IN BOSNIA AND HERZEGOVINA. U.S. Ambassador Cormack's statement on U.S. sanctions against Milorad Dodik. At https://ba.usembassy.gov/information-u-s-sanctions-milorad-dodik/. 
any interests in property in the US or within US jurisdiction and US citizens are banned from engaging in transactions with him. Despite strong lobbying, the sanctions have remained in place. The direct reason for their imposition was the January 9 celebration of a public holiday in Republika Srpska.

The controversy arises every year when a military and civilian parade is held in Banja Luka to mark the Day of Republika Srpska despite the fact that BiH's Constitutional Court ruled in 2015 that marking this holiday excluded non-Serbian citizens and was therefore unconstitutional. The date marks the establishment of Republika Srpska in 1992, as well as celebrating the patron saint of RS, St. Stephen. The Republika Srpska authorities contested the decision of the $\mathrm{BiH}$ Constitutional Court and called for a referendum in 2016 in which a majority of RS citizens supported the celebrations. General Sefer Halilović of the AFBiH threatened that a conflict would flare up if the referendum was held, and his comments were glossed by Minister of Foreign Affairs Ivica Dačić of Serbia as the greatest threat to peace and stability in the region. Bosniak member of the Bosnian Presidency Bakir Izetbegović stated that the referendum was an example of breaching the Dayton Agreement. ${ }^{21}$ Nevertheless, every year, the parade of firefighters, cultural and sports groups takes place to celebrate the Day of Republika Srpska and is accompanied by an army parade. This is deplored both by the international community and the representatives of $\mathrm{BiH}$. Obviously, the presence of a ceremonial unit from the Sixth Infantry Brigade of $\mathrm{AFBiH}$ is not authorised by the $\mathrm{BiH}$ Ministry of Defence but is ordered by the chairman of the Presidency of BiH Mladen Ivanić. The MoD has ordered an investigation into responsibility for this act. ${ }^{22}$ As a former minister of defence, Selmo Cikotić, stated in an interview: "The influence and control of politics or politicians is the biggest and most serious challenge for the functioning and progress of the $\mathrm{AFBiH}$, in both positive and negative terms." 23 The nationalistic politics remains one of the main threats for the AF$\mathrm{BiH}$ and so for the security in $\mathrm{BiH}$ as such. The current negotiations between Kosovo and Serbia about the border adjustments present a threat for sovereignty of the country and could result in strong accent on separatist tendencies in RS, which might be supported by Serbia and Russia.

CONCLUSION - THE UNIFIED ARMED FORCES: MISSION COMPLETED?

My analysis shows that the process of unifying the AFBiH has been one of the more successful of BiH's achievements, though the armed forces still face many challenges

21 Šef ratnog štaba: Ako bude referenduma, neće biti $R S .20 .99 .2016 . \quad$ B92. https://www.b92.net/info/vesti/index.php?yyyy=2016 \& mm=09\&dd=20\&nav_ category=167\&nav_id=1178741.

22 Ministarstvo odbrane BiH: Nismo dali odobrenje za ućešce OSBiH u obilježavanju Dana RSa. Klix-ba. 9. 1. 2017. https://www.klix.ba/vijesti/bih/ministarstvo-odbrane-bih -nismo-dali-odobrenje-za-ucesce-osbih-u-obiljezavanju-dana-rs-a/170109077.

23 CIKOTIĆ, Selmo. Former minister of defence. Questionnaire via email, 18 April 2019, Sarajevo. 
and constraints. The armed forces were downscaled from 167,000 soldiers to 10,000 . The unification effort, from three different armies with three different commands to one unified body under one common minister of defence, not following either the original entities or ethnic lines, is also commendable.

Despite Nato involvement in the Bosnian and Kosovan war against Serbian positions, $\mathrm{BiH}$ identified Nato membership as a priority of its foreign policy as stated in the Bosnia and Herzegovina Defence White Paper, irrespective of the fact that Republika Srpska opposes that aim. Bosnia and Herzegovina also joined the Partnership for Peace (PfP) programme in 2006, while the Individual Partnership Action Plan (IPAP) was agreed with Nato two years later. In 2018, the Alliance decided that $\mathrm{BiH}$ was ready to submit its first Annual National Programme, with the ultimate goal of Nato accession. Further successes of the AFBiH have included participation in the Nato-led International Security Assistance Force (ISAF) in Afghanistan and, following the termination of ISAF at the end of 2014, in Nato's Resolute Support Mission (RSM). The military was praised both nationally and internationally for its actions during the floods in Bosnia in 2014.

The main concerns for the $\mathrm{BiH}$ armed forces include the old equipment which raises security issues, the economic problems of the country and budget constraints, politicisation and ethnicisation - while ongoing nationalism and the unsure future of $\mathrm{BiH}$ remain the greatest external challenges. Only one of my interviewees stated that the armed forces could trigger a conflict, while all of the others believed that it was highly unlikely. Nevertheless, they unanimously stated that, in the event of armed conflict, the army would split along ethnic lines and would take part in the conflict. Not surprisingly, nationalistic politics remains one of the main threats for the $\mathrm{AFBiH}$ and so for security in $\mathrm{BiH}$ and indeed in the whole region. The developments in Republika Srpska and the negotiations between Kosovo and Serbia about border adjustments might result in separatism in RS, which might be supported by Serbia and Russia. Nevertheless, to conclude, the process of unifying AFBiH has been largely successful, unlike the post-conflict building reconstruction in Bosnia and Herzegovina at large. Nevertheless, in order to call it a success, both processes have to be completed concurrently. There can be no successful story to tell about the unification of the Bosnian military without successful post-conflict state building in $\mathrm{BiH}$.

This paper was written as part of the research project SIVARBAL (Proposal for a system of indicators of early warning of possible crisis situations in the Balkans), funded by the Ministry of Defence of the Czech Republic (defence research programme).

Author: Věra Stojarová, PhD., graduated at Palacky University (2002) and Masaryk University (2006). Currently, she works as a researcher at the Department of Political Science of the Faculty of Social Studies at Masaryk University focusing on the security of the Western Balkans. She is the author of several monographs and expert articles focusing on extremism and radicalism in the area of the Western Balkans. 
How to cite: STOJAROVÁ Věra. Unifying the Armed Forces of Bosnia and Herzegovina - mission completed? Vojenské rozhledy. 2019, 28 (3), 071-082. ISSN 1210-3292 (print), 2336-2995 (on-line). Available at: www.vojenskerozhledy.cz 